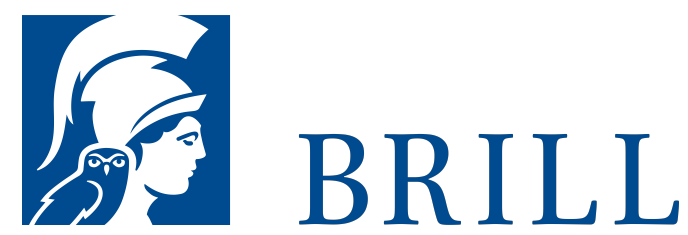

\title{
The Kephalaia of the Teacher
}

The Edited Coptic Manichaean Texts in Translation with Commentary

Author: Iain Gardner

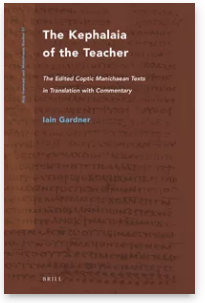

The Kephalaia of the Teacher is the most detailed account available to modern scholarship of the teachings of Mani, and of the universal religion that he founded as the final successor to Buddha, Zarathushtra and Jesus. This volume provides the first complete English translation of the Coptic text (c. 400 CE), together with introduction, commentaries and indices. Topics include the apostleship of Mani, the practices of the Manichaean community, accounts of the heavenly and demonic beings and worlds, as well as discussions of astrology and religious psychology.

In Manichaeism many of the gnostic and dualistic themes of early Christianity achieved the status of a world religion, and the subject is the heir to contemporary interest in heterodoxy and the deconstruction of received histories (see the Nag Hammadi codices).

Readership

All those interested in esoteric and gnostic systems, Christian heresy, and the religions of Late Antiquity; especially graduates and specialists in Coptic and Manichaean studies.

Pages: xli, 307

pp.

Language:

English

Subjects:

Gnosticism \&

Manichaeism,

Biblical Studies

Publisher: Brill

Series:

Nag Hammadi and Manichaean Studies, Volume: 37

E-Book (PDF)

Released online:

26 Oct 2020

ISBN: 978-90-

04-32891-4

List price

USD $\$ 269.00$

Hardback

Publication date:

o1 Feb 1995

ISBN: 978-90-

04-10248-4

List price

USD $\$ 254.00$

Paperback

Publication date:

o8 Sep 2016 
Iain Gardner, Ph.D. (University of Manchester 1983), is Chair of 04-32259-2

List price the Department of Religion and Philosophy at Edith Cowan

University, Western Australia. He is currently editing the newlyfound Coptic and Manichaean texts from Kellis, on behalf of the Dakhleh Oasis Project.

For more information see brill.com

Order information: Order online at brill.com +44330 333 o049 | customerservices@brill.com Submission information: brill.com/authors

Titles published by Brill | Fink, Brill | mentis or Brill | Schöningh: +49(o)71 5413279216 | brill@brocom.de 